[Radiocarbon, Vol. 15, No. 3, 1973, P. 554-565]

\title{
SCOTTISH UNIVERSITIES RESEARCH AND REACTOR CENTRE RADIOCARBON MEASUREMENTS I
}

\author{
D. D. HARKNESS and H. W. WILSON \\ Radiocarbon Laboratory, \\ Scottish Universities Research and Reactor Centre, \\ East Kilbride, Scotland \\ INTRODUCTION
}

The Radiocarbon Laboratory at the Scottish Universities Research and Reactor Centre was established in August 1971. The laboratory is funded by the Natural Environment Research Council and its main function is geochemical investigations in collaboration with the component bodies of the Council and with grant-aided associations. A dating service is also provided to others.

$\mathrm{C}^{14}$ measurement is by liquid scintillation with two counting systems. Details of laboratory design and operational procedures and parameters are described in Harkness and Wilson (1972).

Dubious carbon fractions are carefully removed from all samples and pretreatment is determined in collaboration with the collectors after considering composition, environment, and scientific context of each sample.

Mass spectrometric analysis is carried out for all samples. $\mathrm{C}^{13} / \mathrm{C}^{12}$ ratios are quoted relative to the $\mathrm{PDB}$ limestone standard with a precision of $\pm 1.0 \% o( \pm 2 \sigma)$. In certain cases, e.g., marine shell and groundwater carbon, the standard age adjustment for isotopic fractionation is considered invalid although $\delta \mathrm{C}^{13}$ values are still quoted for general information. Where reported, such sample ages are calculated from $\delta \mathrm{C}^{14}$ and are so indicated in the text. Otherwise, calculations are based on the Lamont formulae (Broecker and Olson, 1961) using the Libby half-life (5570 \pm 30 years) and $95 \%$ of the isotopically corrected activity of NBS oxalic acid as the modern reference standard. Standard deviations quoted $( \pm 1 \sigma)$ describe only the compounded uncertainties associated with sample, background, modern standard, and mass spectrometric measurements (Callow et al., 1965); similarly age limits are defined by the $4 \sigma$ criterion.

ACKNOWLEDGMENTS

We are grateful to the Natural Environment Research Council for financial support and to the Director and staff of the British Museum Research Laboratory for their help with experimental methods. Our thanks are due to colleagues at established dating laboratories who supplied samples for intercalibration and to M. S. Baxter, Glasgow University, and S. M. F. Sheppard, Scottish Universities Research and Reactor Centre for $\mathrm{C}^{13} / \mathrm{C}^{12}$ measurement of early samples. Excellent technical assistance in the laboratory was provided by T. Laing, B. Miller, and J. I. Service. We gratefully acknowledge the cooperation of the submitters for their permission to report this work and for assistance in compiling the data list. 


\section{SAMPLE DESCRIPTIONS}

I. INTERCALIBRATION SAMPLES

Prior to routine measurement of $\mathrm{C}^{14}$ ages, a number of samples were requested from other laboratories for intercalibration.

\section{SRR-1. Mad Brook Valley, Shropshire}

$3500 \pm 70$

1550 B.C.

$$
\delta C^{13}=-29.4 \% \text { o }
$$

Wood from buried tree trunk in Mad Brook Valley at Telford, Shropshire previously dated by Radioactive Dating Lab., Stockholm, IGS-C14/60 (St 3392); $3180 \pm 100$ (Welin et al., 1972).

\section{SRR-2. Madeley Court, Shropshire}

$$
\begin{aligned}
& \quad 1282 \pm 60 \\
& \text { A.D. } 668 \\
& \delta C^{13}=-29.1 \% 0
\end{aligned}
$$

Peat from thrust bore tunnel $\mathrm{N}$ of Madeley Court, Telford, Shropshire previously dated by Radioactive Dating Lab., Stockholm, IGSC14/63; $1130 \pm 100$ (unpub.).

\section{SRR-3. Kilphedir hut circles, Sutherland, Scotland 150 B.c. \\ $\delta C^{13}=-26.2 \%$ o}

Charcoal (Birch-Betula) from hut circle at Kilphedir site previously dated by Lamont Geol. Observatory, Columbia Univ., L-1061; $2100 \pm 80$ (unpub.), and by Glasgow Univ., GU-10; $1908 \pm 60$, GU-1 1; $2064 \pm 55$ (Baxter et al., 1969), GU-67; $1922 \pm 60$ (Ergin et al., 1970).

\section{SRR-4. Elloughton Beck, Yorkshire}

$4029 \pm 70$ 2079 B.C.

$$
\delta C^{13}=-25.7 \%
$$

Wood fragment from layer of organic silt at Elloughton Beck previously dated by Radioactive Dating Lab., Stockholm, IGS-C14/59 (St 3397); $3905 \pm 105$ (Welin et al., 1972).

SRR-5. Wadji

$4656 \pm 60$ 2706 B.C. $\delta C^{13}=-20.8 \%$

Wood from Egyptian tomb previously described and dated by the the British Mus., BM-321; $4496 \pm 80$ (Barker et al., 1971).

\section{SRR-6. Teti}

$3940 \pm 80$ 1990 B.C.

Wood from Egyptian tomb previously described and dated by the British Mus., BM-331; $3770 \pm 85$ (Barker et al., 1971), and by Belfast Radiocarbon Lab., UB-66; $3950 \pm 70$ (Smith et al., 1973).

\section{SRR-7. Wakefield, Yorkshire}

$2569 \pm 80$

619 B.C.

$$
\delta C^{1 s}=-23.3 \%
$$

Wood (Quercus) from gravel pit in valley of $\mathbf{R}$. Calder, Wakefield 
previously dated by Radioactive Dating Lab., Stockholm, IGS-C14/65 (St 3399); $2585 \pm 100$ (Welin et al., 1972).

\section{SRR-8. Wood}

$$
5643 \pm 80
$$

3693 B.C.

$\delta C^{13}=-23.3 \%$

Unid. wood supplied and previously dated by Teledyne Isotopes, I-4987; $5710 \pm 115$ and $5660 \pm 120$ (unpub.).

\section{SRR-9. Redkirk Point, Dumfriesshire}

$12,064 \pm 120$

$$
\delta C^{13}=-26.8 \% \text { o }
$$

Peat from Redkirk Point previously dated by Birmingham Univ., Birm-41; 11,205 \pm 177 (Shotton et al., 1968), and Glasgow Univ., GU-14; $11,828 \pm 105$, GU-15; 12,158 \pm 218 (Baxter et al., 1969).

\section{GEOLOGIC SAMPLES \\ A. United Kingdom}

\section{SRR-10. Loch Clair, 200 to $210 \mathrm{~cm}$}

$$
\begin{gathered}
\mathbf{3 5 2 5} \pm \mathbf{8 0} \\
1575 \text { B.c. } \\
\delta C^{13}=-28.1 \% o
\end{gathered}
$$

Non-calcareous fine detritus lake mud from Core 1, Loch Clair, Wester Ross, Scotland (57 40 N Lat, $5^{\circ} 25^{\prime} \mathrm{W}$ Long). Coll. 1969 and subm. by W. Tutin (W. Pennington), Univ. Leicester. Comment (W.T.): date falls on linear depth-time scale for pollen zone boundaries in NW Scotland (Pennington et al., 1972). Adjacent secs. of core dated, I-4816; $2900 \pm 100$, and I-4815; $4700 \pm 100$. These 3 dates span period during which pine forest disappeared from catchment of Loch Sionascaig. There is no pollen evidence for any contemporaneous deforestation around Loch Clair.

\section{SRR-11. Burnmoor Tarn, 405 to $415 \mathrm{~cm}$}

Non-calcareous fine detritus lake mud overlying expansion of alder (Alnus) at Godwin Zone Boundary VIc/VIIa, Core 5, Burnmoor Tarn, Cumberland, England (54 $24^{\circ} \mathrm{N}$ Lat, $3^{\circ} 17^{\prime} \mathrm{W}$ Long). Coll. 1965 and subm. by W. Tutin. Comment (W.T.): date agrees closely with that of underlying core sec., Y-2361; $7560 \pm 160$ (Stuiver, 1969) and with other dates for this horizon in NW England.

\section{Loch Sionascaig series, Scotland}

Non-calcareous fine detritus lake mud from Core 6, Loch Sionascaig, Wester Ross, Scotland (58 $3^{\prime} \mathrm{N}$ Lat, $5^{\circ} 10^{\prime} \mathrm{W}$ Long). Depth intervals relate to present mud surface. Coll. 1967 and subm. by W. Tutin.

\section{SRR-12. Loch Sionascaig, 275 to $285 \mathrm{~cm}$ \\ 2535 B.C. \\ $\delta C^{13}=-21.2 \%$ \\ Comment (W.T.): sample represents topmost $10 \mathrm{~cm}$ of sec. of core}

$4485 \pm 100$ 
within which sediments contain 50 to $60 \%$ pine pollen (as \% of total pollen). Local deforestation must have begun soon after this date. The pollen zone boundary N Scotland Vii/VI at Loch Sionascaig is drawn at the upper limit of this sample.

\section{SRR-13. Loch Sionaseaig, 400 to $410 \mathrm{~cm}$}

Comment (W.T.): date agrees with Y-2364; $7880 \pm 160$ in that increase in pine pollen to 50 to $60 \%$ of the total began soon after 6000 B.C. and was completed by $5186 \pm 130$ B.c. at this site.

\section{SRR-14. Loch Sionascaig, 460 to $470 \mathrm{~cm}$}

$$
\begin{gathered}
8523 \pm 120 \\
6573 \text { в.C. } \\
\delta C^{13}=-25.3 \%
\end{gathered}
$$

Comment (W.T.): sample represents middle of birch-hazel pollen zone (N Scotland III) which preceded Pine Zones IV and V.

\section{SRR-15. Loch Sionascaig, 500 to $510 \mathrm{~cm}$}

$9474 \pm 160$

7524 B.C.

$$
\delta C^{13}=-23.1 \%
$$

Comment (W.T.): sample represents middle of juniper zone (N Scotland II) below birch-hazel zone, and indicates delay in expansion of postglacial birch forest in N Scotland as compared with S Britain.

General Comment (W.T.): data fall on linear depth-time scale indicated by Y-2362; $4020 \pm 100, \mathrm{Y}-2363 ; 6250 \pm 140$, and Y-2364; $7880 \pm 160$ (Stuiver, 1969) and confirm sediment accumulation rates as uniform over the period studied. Data establish dates for pollen zone boundaries in NW Scotland (Pennington et al., 1972).

\section{Blea Tarn series, England}

Postglacial non-calcareous fine detritus lake mud from Blea Tarn, Westmorland, England (54 $21^{\prime} \mathrm{N}$ Lat, $3^{\circ} 5^{\prime} \mathrm{W}$ Long). Core 1 obtained from deepest part of tarn $(8.25 \mathrm{~m}$ water) with $6 \mathrm{~m}$ Mackereth corer. Depth intervals relate to present mud surface. Coll. 1971 and subm. by W. Tutin.

SRR-16. Blea Tarn, 94 to $100 \mathrm{~cm}$

SRR-17. Blea Tarn, 120 to $126 \mathrm{~cm}$

SRR-18. Blea Tarn, 140 to $150 \mathrm{~cm}$

SRR-19. Blea Tarn, 210 to $215 \mathrm{~cm}$

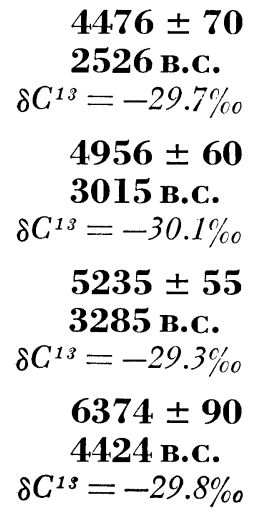


SRR-20. Blea Tarn, 250 to $260 \mathrm{~cm}$

SRR-21. Blea Tarn, 290 to $300 \mathrm{~cm}$

SRR-22. Blea Tarn, 320 to $330 \mathrm{~cm}$

SRR-23. Blea Tarn, 352 to $357 \mathrm{~cm}$

$$
\begin{aligned}
& 7264 \pm 70 \\
& \text { 5314 B.C. } \\
& \delta G^{13}=-29.2 \% \\
& \mathbf{8 5 1 4} \pm 85 \\
& \text { 6564 B.C. } \\
& \delta C^{13}=-30.0 \% \\
& 9012 \pm 100 \\
& 7062 \text { B.C. } \\
& \delta C^{13}=-29.9 \% \\
& 9872 \pm 180 \\
& 7922 \text { в.C. } \\
& \delta C^{13}=-29.6 \%
\end{aligned}
$$

General Comment (W.T.): data provide a time scale for annual pollen deposition rates (Pennington et al., 1972). Dates for Elm Decline, Godwin Zone Boundary VIIa/VIIb, as given by SRR-17 and SRR-18, agree closely with this horizon in a previous Blea Tarn core, K-957; $5100 \pm 120$, K-958; $5320 \pm 120$, and K-959; $5530 \pm 120$ (Tauber, 1966) and with many dates for this horizon in NW Europe (Hibbert et al., 1971). Detailed absolute pollen analysis over Elm Decline horizon is in press (Pennington, 1973). Remainder of profile is being analyzed and a complete postglacial absolute pollen diagram will be pub. later.

\section{Loch a'Chroisg series, Scotland}

Non-calcareous fine detritus lake mud from Loch a'Chroisg, Wester Ross, Scotland $\left(57^{\circ} 30^{\prime} \mathrm{N}\right.$ Lat, $5^{\circ} 10^{\prime} \mathrm{W}$ Long). Samples coll. with $6 \mathrm{~m}$ Mackereth corer, depth intervals relate to present mud surface. Coll. 1971 and subm. by W. Tutin.

SRR-53. Loch a'Chroisg, 290 to $300 \mathrm{~cm}$

\section{SRR-54. Loch a'Chroisg, 340 to $346 \mathrm{~cm}$}

\section{SRR-55. Loch a'Chroisg, 390 to $400 \mathrm{~cm}$}

$$
\begin{gathered}
2893 \pm 60 \\
943 \text { в.C. } \\
\delta C^{13}=-29.1 \% \circ \\
\mathbf{3 5 8 3} \pm \mathbf{7 5} \\
\mathbf{1 6 3 3} \text { в.C. } \\
\delta C^{13}=-28.7 \% \circ \\
\mathbf{4 1 4 9} \pm \mathbf{7 0} \\
\mathbf{2 1 9 9} \text { в.C. } \\
\delta C^{13}=-28.5 \%
\end{gathered}
$$

General Comment (W.T.): dates span sec. of core in which pollen content of sediments record a steep decline in ann. deposition of pine pollen per unit area. This is accompanied by an absolute increase in the numbers of grains/yr of bog plant pollen. Replacement of pine forest by blanket bog on this catchment, therefore, probably took place at approx. same time as deforestation at Loch Sionascaig. The absolute pollen diagram for this horizon is in press (Pennington, 1973). 
Valley Bog series, England

Peat from Valley Bog, Moorhouse Natl. Nature Reserve, Upper Teesdale, England (54 $42^{\prime}$ N Lat, $2^{\circ} 22^{\prime}$ W Long), Natl. Grid Ref. 35763331 , at alt. 549m (Newlyn). Sample profile coll. using Russian peat borer, and depths relate to present ground surface. Coll. 1970 and subm. by C. Chambers and J. Turner, Univ. Durham.

This series is assoc. with a pollen diagram from Valley Bog constructed by C. C. with a view to dating major vegetational changes already apparent on Johnson and Dunham's diagram (1963).

SRR-88. Valley Bog, 152.5 to $157.5 \mathrm{~cm}$

$2212 \pm 55$ 262 B.C.

Sample overlies 1st major rise in Plantago pollen.

$$
\delta C^{13}=-26.3 \%
$$

SRR-89. Valley Bog, 157.5 to $162.5 \mathrm{~cm}$

$2175 \pm 45$

225 B.C.

$\delta C^{13}=-26.5 \%$

Sample underlies 1st major rise in Plantago pollen. Comment (J.T.): SRR-88 and -89 indicate that woodland of region was cleared for 1st time during Iron age.

SRR-90. Valley Bog, 302.5 to $307.5 \mathrm{~cm}$

$4596 \pm 60$

2646 B.C.

Sample overlies 2nd elm decline.

$$
\delta C^{13}=-26.9 \%
$$

\section{SRR-91. Valley Bog, 312.5 to $317.5 \mathrm{~cm}$}

$4794 \pm 55$

2844 B.c.

$\delta C^{13}=-27.1 \%$

Sample underlies 2nd elm decline. Comment (J.T.): SRR-90 and -91 indicated that 2nd decrease in elm pollen frequency occurred ca. 4700 B.P., a little later than average date for this horizon in Britain but not significantly outside range of dates.

\section{SRR-92. Valley Bog, 421 to $426 \mathrm{~cm}$}

Sample overlies 1st elm decline.

\section{SRR-93. Valley Bog, 426 to $431 \mathrm{~cm}$}

$5950 \pm 60$

4000 B.c.

$\delta C^{13}=-27.1 \%$

$5945 \pm 50$

3995 B.c.

$\delta C^{13}=-26.2 \%$

Sample underlies 1st elm decline. Comment (J.T.): SRR-92 and -93 indicate that 1st decrease in elm pollen frequency occurred ca. 5950 в.P., significantly earlier than normal range of dates for this horizon in Britain.

SRR-94. Valley Bog, 502.5 to $507.5 \mathrm{~cm}$

$6714 \pm 74$

4764 B.C.

Sample overlies decrease in pine pollen. 


\section{SRR-95. Valley Bog, 512.5 to $517.5 \mathrm{~cm}$

Sample underlies decrease in pine pollen. Comment (J.T.): SRR-94 and -95 indicate that pine remained important in forests of area until ca. 6700 B.P., substantially later than in Cow Green Reservoir area, further down the Tees Valley, where it began to decrease after $8070 \pm 170$ B.P. and completely disappeared by $5770 \pm 110$ B.P.

\section{Neasham Fen series, England}

Peat and detritus mud from infilled kettle hole at Neasham Fen, Darlington, England (54 $30^{\prime} \mathrm{N}$ Lat, $1^{\circ} 29^{\prime} \mathrm{W}$ Long), Natl. Grid Ref. NZ 331116. Sample core coll. using Russian peat borer; depths relate to present ground surface. Coll. 1971 by C. Chambers; subm. by J. Turner. Series is assoc. with pollen diagram prepared by C. C. and dates all the major vegetational changes.

\section{SRR-96. Neasham Fen, 55 to $60 \mathrm{~cm}$}

$1213 \pm 60$

\section{A.D. 737}

$\delta C^{13}=-25.9 \%$

Sedge peat related to final expansion of Cyperaceae, Gramineae, and Plantago pollen frequencies. Comment (J.T.): indicates extensive forest clearance in area during 8th century A.D.

\section{SRR-97. Neasham Fen, 100 to $105 \mathrm{~cm}$}

$\mathbf{2 8 0 4} \pm \mathbf{8 0}$

854 B.C.

$$
\delta C^{13}=-30.7 \%
$$

Muddy peat dating end of 1st main clearance phase.

\section{SRR-98. Neasham Fen, 105 to $110 \mathrm{~cm}$}

Muddy peat, sec. dated in view of apparent age/depth anomaly between SRR-97 and -100.

SRR-99. Neasham Fen, 135 to $140 \mathrm{~cm}$

Muddy peat, sec. dated in view of apparent age/depth anomaly between SRR-97 and -100.

\section{SRR-100. Neasham Fen, 140 to $145 \mathrm{~cm}$}

$$
\begin{gathered}
2488 \pm 75 \\
\mathbf{5 3 8} \text { в.c. } \\
\delta C^{13}=-28.4 \% \circ
\end{gathered}
$$

Muddy peat, corresponds to beginning of 1st major phase of forest clearance.

General Comment (J.T.): dates SRR-97-100 are not in expected order of depth, and even after adjustment to Bristlecone Pine calibration curve (Suess, 1970) remain anomalous. However, series indicates some forest clearance during lst half of lst millennium B.c. 
SRR-101. Neasham Fen, 245 to $250 \mathrm{~cm}$

$3242 \pm 70$

1292 B.C.

$\delta C^{13}=-27.2 \%$

Detritus mud, dates minor phase of forest clearance to Bronze age.

\section{SRR-102. Neasham Fen, 335 to $340 \mathrm{~cm}$}

$5468 \pm 80$

3518 B.C.

$\delta C^{13}=-31.6 \%$

Detritus mud corresponds to level at which Ulmus pollen frequency falls to $<5 \%$ total tree pollen. Comment (J.T.): date seems early side for elm decline in Britain.

\section{SRR-103. Neasham Fen, 410 to $415 \mathrm{~cm}$}

$$
\begin{aligned}
& \mathbf{6 9 6 2} \pm 90 \\
& \mathbf{5 0 1 2} \text { в.C. } \\
& \delta C^{13}=-31.2 \%
\end{aligned}
$$

Detritus mud corresponds to level at which Alnus pollen frequencies rise. Comment (J.T.): date is similar to others obtained for VI/VIIa pollen zone boundary in Britain.

\section{SRR-104. Neasham Fen, 530 to $535 \mathrm{~cm}$}

$8202 \pm 95$

6252 B.C.

$\delta C^{13}=-29.5 \%$

Detritus mud corresponds to horizon at which Quercus pollen frequencies reach 1st high level viz. VIa/b pollen zone boundary.

\section{SRR-105. Neasham Fen, 580 to $585 \mathrm{~cm}$}

$8829 \pm 120$

6879 B.C.

$\delta C^{13}=-28.2 \%$

Detritus mud corresponds to horizon at which Ulmus pollen frequencies reach 1st high level viz. beginning of Pollen Zone VIa.

\section{SRR-106. Neasham Fen, 590 to $595 \mathrm{~cm}$}

$9082 \pm 90$

7132 B.C.

$\delta C^{13}=-29.4 \%$

Detritus mud corresponds to level of 1st high Corylus pollen frequencies viz. Pollen Zone V.

\section{Weelhead Moss series, England}

Sedge peat from Weelhead Moss, Upper Teesdale, England $\left(54^{\circ} 40^{\prime}\right.$ N Lat, $2^{\circ} 18^{\prime}$ W Long), Natl. Grif Ref. NY 805305. Samples coll. from peat block cut from side of freshly dug pit; depths relate to present bog surface. Coll. 1969 and subm. by J. Turner. Dates support a series previously measured by Gakushuin Lab. viz. GaK-2913 to -2919, and are assoc. with a pollen diagram (Turner et al., in press).

\section{SRR-107. Weelhead Moss, $239 \mathrm{~cm}$}

$$
\begin{gathered}
\mathbf{6 2 0 2} \pm 70 \\
4252 \text { в.c. } \\
\delta C^{13}=-29.6 \% o
\end{gathered}
$$

Sample from junction of moderately humified layer $(70$ to $239 \mathrm{~cm})$ and a partly humified layer $(239$ to $360 \mathrm{~cm})$, and corresponds to broad transition on pollen diagram from Zone VI to VIIa. 
SRR-108. Weelhead Moss, $337 \mathrm{~cm}$

$$
\begin{gathered}
\mathbf{8 0 5 7} \pm \mathbf{\pm 5} \\
\mathbf{6 1 0 7} \text { B.C. } \\
\delta C^{13}=-30.1 \% 0
\end{gathered}
$$

Comment (J.T.): sample contained a Zone VI pollen assemblage and indicates that peat from $337 \mathrm{~cm}$ to $280 \mathrm{~cm}$ formed rapidly.

\section{SRR-26. Muirfad Flow, Kirkcudbrightshire}

$$
4746 \pm 50
$$

2796 B.C.

$\delta C^{13}=-20.3 \%$

Wood fragments from junction of thick peat bed above and Flandrian estuarine/marine deposits below, $+7.92 \mathrm{~m}$ alt., $300 \mathrm{~m} \mathrm{SE}$ of confluence of Palnure Burn and R. Cree. Kirkcudbrightshire, Scotland ( $54^{\circ} 55^{\prime} \mathrm{N}$ Lat, $4^{\circ} 2^{\prime}$ W Long), Natl. Grid Ref. NX 453620. Coll. 1971 and subm. by W. G. Jardine, Univ. Glasgow. Comment (W.G.J.): date is approx. minimum for end of main Flandrian marine transgression in Wigtown Bay area of Solway Firth.

\section{SRR-24. Chesil Beach, Abbotsbury}

$$
\begin{gathered}
\mathbf{4 0 2 3} \pm \mathbf{5 0} \\
\mathbf{2 0 7 3} \text { B.C. } \\
\delta C^{13}=-28.3 \%
\end{gathered}
$$

Phragmites peat from eroded raft, $2.3 \times 2.1 \times 0.8 \mathrm{~m}$, deposited on Abbotsbury Beach, England ( $50^{\circ} 39^{\prime} \mathrm{N}$ Lat, $2^{\circ} 36^{\prime} \mathrm{W}$ Long), Natl. Grid Ref. SY 568838. Coll. Dec. 1970 by M. W. Blackley; subm. by A. P. Carr, Unit Coastal Sedimentation, Taunton, Somerset. Alternative sample previously dated by Teledyne Isotopes, I-5670; $5270 \pm 110$ (unpub.).

\section{SRR-25. Chesil Beach, Abbotsbury}

$4095 \pm 60$ 2145 B.C.

$$
\delta C^{13}=-28.5 \%
$$

Further determination of peat, above, in view of age discrepancy between I-5670 and SRR-24. SRR-24 was washed in hot $0.5 \mathrm{M} \mathrm{KOH}$ and acidified with $\mathrm{HC} 1$ before $\mathrm{C}^{14}$ assay. Simultaneous analysis by Univ. Cambridge of various carbonaceous fractions from this sample source gave, Q-1028; $4234 \pm 60$, Q-1029; $4251 \pm 60$, and Q-1030; $5058 \pm 70$ (Switzur and West, 1972).

General Comment (D.D.H.): non-contemporaneous fractions of plant debris are apparent in these peat rafts. Wood fragments, reported by Univ. Cambridge, were absent in material forwarded to SURRC. Date range measured for this source emphasizes importance of careful sample selection and identification and of lab. pretreatment.

\section{B. Norway}

\section{Tunsbergdal series, $S$ Norway}

Peat and wood fragments from interstadial stratum buried in glacial till at ca. $150 \mathrm{~m}$ beyond snout of Tunsbergdalsbre/Jostedals ice cap, Tunsbergdal Amphitheatre, Jostedals, S Norway $\left(61^{\circ} 31^{\prime} \mathrm{N}\right.$ Lat, $7^{\circ} 20^{\prime} \mathrm{E}$ Long), Norwegian Natl. Grid Ref. 401/6823, alt. 500m. The raft of erractic peat ca. $1.5 \mathrm{~m}$ thick overlies ca. $1.8 \mathrm{~m}$ weathered till and is covered 
by ca. $4.0 \mathrm{~m}$ fresh till. Coll. 1971 and subm. by D. N. Mottershead, Portsmouth Polytech.

Possible age variation among carbonaceous fractions of a sample coll. from base of peat raft was investigated after chemical separation.

SRR-50. Tunsbergdal, basal layer

$8083 \pm 100$

Composite sample washed in hot water, homogenized.

\section{SRR-51. Tunsbergdal, basal layer}

6133 B.C.

$\delta C^{13}=-25.0 \%$

$\delta C^{13}=-23.7 \%$ 1.0 M KOH, final residue acidified with HCI and washed in water.

\section{SRR-52. Tunsbergdal, basal layer}

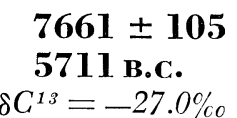

Alkali soluble fraction (humics), recovered after acidification of supernatant from caustic leach.

General Comment (D.D.H.): composite wood and peat are contemporaneous; contamination by humic acids appears insignificant.

\section{SRR-166. Tunsbergdal, Upper layer}

$$
\begin{gathered}
\mathbf{3 8 5 5} \pm \mathbf{5 5} \\
\mathbf{1 9 0 5} \text { в.C. } \\
\delta C^{18}=-24.3 \% o
\end{gathered}
$$

Sample from ca. $10 \mathrm{~cm}$ below top surface of peat raft. Pretreated as for SRR-50.

General Comment (D.N.M.): initial peat accumulation ca. 8400 в.P. indicates glacier of smaller extent than at present. Readvance of ice ca. 4000 B.P. moved peat to its present position and deposited overlying till.

\section{Greece}

\section{SRR-82. Lake Kopais, S Greece}

$$
\begin{aligned}
& 5205 \pm 120 \\
& 3255 \text { в.C. }
\end{aligned}
$$$$
\delta C^{13}=-30.0 \%
$$

Peat from temporary excavation at Lake Kopais, S Greece $\left(38^{\circ} 28^{\prime} \mathrm{N}\right.$ Lat, $24^{\circ} 07^{\prime} \mathrm{E}$ Long). Date assoc. with a pollen diagram and indicates 1 st major clearance of trees in area. Coll. 1964 by J. Turner and C. Turner; subm. by J. Turner.

\section{Lake Philippi series, NE Greece}

Muddy peat from Sites I and III at Lake Philippi, NE Greece $\left(40^{\circ} 57^{\prime}\right.$ $\mathrm{N}$ Lat, $24^{\circ} 18^{\prime} \mathrm{E}$ Long). Samples assoc. with pollen diagrams Philippi I and Philippi III; depths quoted relate to present ground surface. Coll. 1970 by J. Greig and C. Chambers; subm. by J. Turner. 
SRR-83. Lake Philippi Site I, 200cm

Dates base of pollen diagram Philippi I.

\section{SRR-84. Lake Philippi Site III, 70cm}

Dates decrease in tree pollen and increase in grass pollen.

\section{SRR-85. Lake Philippi Site III, $140 \mathrm{~cm}$}

Dates level for increase in Cyperaceae pollen.

\section{SRR-86. Lake Philippi Site III, 345 to $350 \mathrm{~cm}$}

Dates base of pollen diagram Philippi III.

$$
\text { D. Libya }
$$

$$
\begin{gathered}
\mathbf{5 0 3 1} \pm \mathbf{1 8 0} \\
\mathbf{3 0 8 1} \text { B.c. } \\
\delta C^{13}=-27.0 \% \circ \\
\\
\mathbf{2 8 6 7} \pm \mathbf{6 0} \\
\mathbf{9 1 7} \text { B.c. } \\
\delta C^{13}=-27.3 \% \text { o }
\end{gathered}
$$

\section{Groundwater series}

Dissolved carbonate/bicarbonate coll. from groundwater using ion exchange columns (Crosby and Chatters, 1965). Data reported are measured $\mathrm{C}^{14}$ ages, no attempt is made here to adjust these ages for dead carbonate contribution. Samples coll. 1972 and subm. by W. M. Edmunds, Hydrogeol. Dept. Inst. Geol. Sci., London.

SRR-75. Kufra, Well 9

$$
\begin{array}{r}
\mathbf{2 4 , 1 0 0} \pm \mathbf{1 5 0} * \\
\delta C^{13}=-10.1 \%
\end{array}
$$

Groundwater pumped from Nubian sandstone at depth 122 to $320 \mathrm{~m}$ below ground level, Kufra Agric. Project Well 9, Kufra Oasis, S Libya (24 $13^{\prime}$ N Lat, $23^{\circ} 17^{\prime}$ E Long).

SRR-76. Kufra, Well 11

$$
\begin{array}{r}
>\mathbf{4 7 , 8 0 0 *} \\
\delta C^{13}=-10.7 \% 0
\end{array}
$$

Groundwater pumped from Nubian sandstone at depth 122 to $232 \mathrm{~m}$ below ground level. Well $11 \mathrm{ca}$. $1 \mathrm{~km}$ from Well 9, above.

SRR-77. Libya D Field, Well 52-103D

$14,130 \pm 425^{*}$ $\delta C^{13}=-10.4 \%$

Groundwater pumped from Quaternary sands at depth 137 to $168 \mathrm{~m}$ below ground level. Occidental Oil Co., water Well 52-103 D, Surt Basin Libya ( $28^{\circ} 54^{\prime} \mathrm{N}$ Lat, $20^{\circ} 56^{\prime} \mathrm{E}$ Long).

\section{Kufra series, S Libya}

Wood fragments from extensive horizon buried in quartz sand, sampled during drilling operations at Kufra Oasis, S Libya $\left(24^{\circ} 13^{\prime} \mathrm{N}\right.$ Lat, $23^{\circ}$ 17' E Long). Coll. 1971 by A. Craig; subm. by W. M. Edmunds.

* Age is not adjusted for isotopic fractionation. 
SRR-78. Kufra Borehole C81, 265 to $267 \mathrm{~m}$

SRR-79. Kufra Borehole C81, 186 to $210 \mathrm{~m}$

SRR-80. Kufra Borehole C53, 192 to $198 m$

\section{SRR-81. Angila D Field}

$>45,000$

$\delta C^{13}=-23.8 \%$

$>48,000$

$\delta C^{13}=-22.4 \%$

$>48,000$

$\delta C^{13}=-21.7 \%$

$788 \pm 50$

A.D. 1162

$\delta C^{13}=-16.7 \%$

Plant debris (palm) in sand/clay/gypsum matrix, excavated from ca. $1.5 \mathrm{~m}$ below top of isolated soil pedestal NE of exploratory oil Well

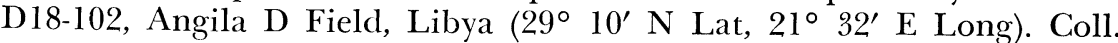
1972 and subm. by W. M. Edmunds.

\section{REFERENCES}

Barker, H., Burleigh, R., and Mecks, N., 1971, British Museum natural radiocarbon measurements VII: Radiocarbon, v. 13, p. 157-188.

Baxter, M. S., Ergin, M., and Walton, A., 1969, Glasgow University radiocarbon meas urements I: Radiocarbon, v. 11, p. 43-52.

Broecker, W. S. and Olson, E. A., 1961, Lamont radiocarbon measurements VIII: Radiocarbon, v, 3, p. 176-204.

Callow, W. J., Baker, M. J., and Hassal, G. I., 1965, National Physical Laboratory radiocarbon measurements III: Radiocarbon, v. 7, p. 156-161.

Crosby, J. W., III and Chatters, R. M., 1965, New techniques of water sampling for carbon-14 analysis: Jour. Geophys. Research, v. 70, p. 2839-2844.

Ergin, M., Harkness, D. D., and Walton, A., 1970, Glasgow University radiocarbon measurements II: Radiocarbon, v. 12, p. 486-495.

Harkness, D. D. and Wilson, H. W., 1972, Some applications in radiocarbon measurement at the Scottish Research Reactor Centre: 8th internatl. conf. on radiocarbon dating Proc., Lower Hutt, New Zealand.

Hibbert, Switzur, V. R. and West, R., 1971: Royal Soc. [London] Proc., ser. B, 177, p. 174.

Johnson, G. A. L. and Dunham, K. C., 1963, The geology of Moor House: Nature Conservancy Mon., no. 2, HMSO, London.

Pennington, W., 1973, Absolute pollen frequencies in the sediments of lakes of different morphometry: Jour. Ecology, in press.

Pennington, W., Haworth, Bonny, and Lishman, 1972, Lake sediments in northern Scotland: Royal Soc. [London] Philos. Trans., ser. B, in press.

Shotton, F. W., Blundell, D. J., and Williams, R. E. G., 1968, Birmingham University radiocarbon dates II: Radiocarbon, v. 10, p. 200-206.

Smith, A. G., Pearson, G. W., and Pilcher, J. R., 1973, Belfast radiocarbon dates V: Radiocarbon, v. 15, p. 212-228.

Stuiver, Minze, 1969, Yale natural radiocarbon measurements IX: Radiocarbon, v. 11, p. $545-658$.

Suess, H. E., 1970, Bristlecone pine calibration of the radiocarbon time-scale 5200 B.C. to the present: 12th Nobel symposium Proc., Stockholm, Almquist and Wiksell, p. 303-311.

Switzur, V. R. and West, R. G., 1973, University of Cambridge natural radiocarbon measurements XI: Radiocarbon, v. 15, p. 156-164.

Tauber, Henrik, 1966, Copenhagen radiocarbon dates VII: Radiocarbon, v. 8, p. 213-234.

Turner, J., et al., 1973, History of the vegetation and flora of Wittybank Fell and the Cow Green Reservoir Basin: Royal Soc. [London] Proc., ser. B, 265, p. 327-408.

W'elin, E., Engstrand, L., and Vaczy, S., 1972, Institute of Geological Sciences radiocarbon dates III: Radiocarbon, v. 14, p. 331-335. 